\title{
Forensic Odontology: A Boon to Community in Medico-legal Affairs
}

\author{
Ramasamy Chidambaram ${ }^{1}$ \\ 'Faculty of Dentistry, Department of Prosthodontics, AIMST University, Kedah Darul Aman, Malaysia.
}

\begin{abstract}
Forensic odontology is a sub-discipline of dental science which involves the relationship between dentistry and the law. The specialty of forensic odontology is applied in radiographic investigation, human bite marks analysis, anthropologic examination and during mass disasters. Besides the fact that radiographs require pretentious laboratory, it is still claimed to be a facile, rapid, non-invasive method of age identification in the deceased. The budding DNA technology has conquered the traditional procedures and currently being contemplated as chief investigating tool in revealing the hidden mysteries of victims and suspects, especially in hopeless circumstances. Forensic odontology has played a chief role in solving cold cases and proved to be strong evidence in the court of law. Systematic collection of dental records and preservation of the same would marshal the legal officials in identification of the deceased. To serve the forensic operation and legal authorities, dental professionals need to be familiar with the basics of forensic odontology, which would create a consciousness to preserve the dental data. The aim of this paper is to emphasize the vital applications of forensic odontology in medico-legal issues. Conjointly the recent advancements applied in forensic human identification have been updated.
\end{abstract}

Keywords: bite marks; dental records; forensic identification; mass disaster; medico-legal issues.

\section{INTRODUCTION}

Forensic odontology has much to contribute in human identification and medico-legal affairs. It is the branch of dentistry that handles the legal issues of dental treatment and in particular the use of dental records to identify victims of crimes. Lollia Paulina, in the year 49 A.D, was the first reported case of forensic odontology. ${ }^{1}$ This branch has served many years in identifying victims and suspects in mass disasters, abuse and organized crimes. ${ }^{2}$ Justified fact that dental restorations and human teeth remain stable over a long spell, even in immeasurable situations like fire, forensic odontology can be of key aspect in identifying mutilated corpses. ${ }^{3}$ Under these crucial circumstances, forensic dental identification is highly valuable. ${ }^{4}$

Literature has provided sufficient information related to forensic odontology. Meanwhile, scarce reports are available which narrate the evolution of forensic applications and recent achievements simultaneously. Present paper aims to document the historical journey of forensic odontology from its origin to present day contributions with a note on the contemporary approaches.

\section{LITERATURE SEARCH}

The pubmed data base were searched using the following terms in association with "bite marks forensic", "bite mark evidence", "human bite marks", "disaster management", "disaster victim identification",

Correspondence: Dr. Ramasamy Chidambaram, Department of of Prosthodontics, Faculty of Dentistry, AIMST University, Jalan BedongSemeling, 08100 Semeling, Kedah Darul Aman, Malaysia. Email: dr.ramasamyc@gmail.com, Phone: +60164724370. 
“disaster medicine", "disaster preparedness", "disaster response", "forensic anthropology", "forensic autopsy", "forensic analysis", "forensic age", "forensic dentistry", "forensic DNA", "forensic genetics", "forensic identification", "forensic odontology", "forensic medicine", "dental records", "identification corpses", "natural disaster", "medico-legal issues", "postmortem forensic", "radiographic evaluation", "panoramic radiograph", "digital radiography", "cheiloscopy", "palatal rugoscopy", "sexual assault", "sexual abuse", "violent crimes", "violent death". The literature search was restricted to articles in English which were documented during the period 19702014. The focus of search was aimed towards the applications of forensic odontology in medico-legal issues. Additional information was retrieved from case reports, newspaper articles, dental magazines, authenticated web sites and textbooks to benefact the readers. Obtained data pertinent to the specialty of forensic odontology was isolated so as to deliver rationalized information. The above mentioned details were gathered during September 2014 in Faculty of Dentistry, AIMST University, Malaysia.

\section{FORENSIC ODONTOLOGY APPLICATIONS}

Forensic odontology requires a multidisciplinary knowledge and approach as it incorporates most of the tributaries of dentistry. It encompasses the management, examination, evaluation and presentation of dental evidence in criminal or civil proceeding and research. ${ }^{5}$ Cardinal role of a forensic dentist is to identify the deceased individuals. ${ }^{6}$ Shamim, proposed the new working classification of forensic odontology based on the various dental tributaries. ${ }^{2}$ The disciplines encompass oral pathology, oral medicine and radiology, oral and maxillofacial surgery, paedodontics, periodontics, conservative dentistry and endodontics, prosthodontics, orthodontics and preventive and community dentistry. The important dental factors employed during investigation include the total number of tooth, caries, restoration, drifting of teeth, endodontic treatment, intra oral radiographic trabecular pattern, prosthesis and occlusal relation. ${ }^{7}$

\section{RADIOGRAPHIC INVESTIGATION}

Radiographs guide the forensic dentist in estimating the age of unknown individual. Comparison of ante-mortem and post-mortem radiograph is recognized as one of the moral approaches in human identification. Root and tooth analysis, abnormal jaw findings, restoration contours, caries, endodontic therapy can be inspected by radiographic examination. ${ }^{8}$ Dental $x$ rays, taken initially during the diagnosis and treatment planning can be correlated with dental status of the cadaver. ${ }^{9}$ Mandibular third molars considered to be the last tooth to erupt in the oral cavity is a reliable sign for evaluation of age in the early twenties. ${ }^{10}$ The diversification in dental features such as morphology, angulations of tooth, degree of restoration render satisfactory information and thereby comparison with ante- mortem radiographs yield authentic results. ${ }^{11}$ Human dentition follows a sequential cascade of tooth eruption, from the intrauterine life till all of the permanent teeth are erupted, which further assures that the age can be accurately calculated by radiograph interpretation. ${ }^{12}$ Radiographs guide the forensic dentists in primary identification, even when the body is beyond recognition. ${ }^{13}$ Regardless of the former statement; the real job is in recognizing the persons who are edentulous, where most of the hard tissue details are not present. Fortunately, the report documented by Borrman et al., on radiographic bone pattern facilitated the forensic team in solving the crisis of edentulous persons. ${ }^{11}$ Dental morphology still prevail to be one among the effective approach for post-mortem recognition because of the intra oral hard tissue findings, which may be the only positive source of revealing identity when the other features are missing. ${ }^{14}$

Currently forensic dentists utilize the service of computer aided software, automated dental identification (ADIS) wherein the system retrieves the best matches from an ante mortem database. ${ }^{15}$ Furthermore, with the increasing dental records and data involved in natural disasters, the forensic dentists are exposed to a fatigue environment. The traditional methods of radiographic analysis require more duration and human service which poses a burden to the forensic team. Application of the ADIS reduces the workload of forensic dentists and meanwhile the job is also accomplished with accuracy. Recent techniques include volume matching of teeth imaged by cone beam CT (Computed Tomography) and the X-ray microfocus CT to obtain pulp vs. tooth volume ratio. They produce better resolution of the root canal when compared with the conventional $x$ rays. ${ }^{16}$ Apart from the protocol that the radiographs demand an expensive laboratory, it is still claimed to be simple, rapid, non -invasive method of age identification in the deceased. ${ }^{17}$

\section{HUMAN BITE MARK ANALYSIS}

Human bite mark is often considered with violent crimes. It is recommended as hard evidence under the law. ${ }^{18}$ Sexual violence and child abuse are known to be the major acts, where the bite marks are seen. Maxillary and mandibular anterior teeth turn out to be the prime factors in causing bite marks. Precise information can be anticipated if the suspect has dentures 
and crowns. Assailant uses the teeth as armor whilst the sufferer use them in safeguarding. ${ }^{19}$ Human bite marks vary in their forms, depending on the part of the body due to the texture of human skin. Broadly the bite marks consist of superficial injury and lacerated skin owing to the bite. ${ }^{20}$ Bite marks can be noticed after a physical encounter between grownups and juvenile, during sexual attack by a grown-up on a youngster, especially in forced sexual attack where bite marks are prominent in the breasts. ${ }^{21}$ Pattern of bite mark is distinguished with the unique features of the dentition of the alleged person. At occasions, bite mark patterns are noted in food-stuffs. ${ }^{18}$ Absence of distortions in the food, facilitates the forensic dentist in acquiring accurate details from the bite marks. ${ }^{22}$ The examination of bite marks, demand an instant response by the forensic dentist. Within short course of time (10-20 minutes), the bite mark may diminish in size and thereby requires the documentation to be performed at the initial stages. ${ }^{23}$ Literature confirm that, the utilization of bite mark evidence began around 1870 with the Ohio vs. Robinson case. ${ }^{24}$ The major breakthrough was seen in cases which involved rape, serial killing of innocent people, where in the victim's bite marks matched with the suspect. ${ }^{25-27}$ The renowned trial of Ted Bundy during 1970's is still considered to be a milestone in medico-legal affairs where in the suspect was finally found guilty for murdering more than 30 women with his evident bite marks. Collectively with human brilliance and technological advancement the hidden mystery in uncertain forensic cases has been disclosed. The bite mark evidence is still a vital tool in solving cold cases which remained a mystery for decades. ${ }^{28,29}$

The search for the advanced forensic technique is still continuing in human identification. Beneficially with $\mathrm{Di}$ Ribonucleic Acid (DNA) technology, genetic material can be recovered through the saliva deposited in the skin. Numerous organic substances like teeth, body and bone tissues, hair bulb, biopsy fragment, saliva and blood can be utilized for segregation of DNA. ${ }^{30}$ In the current day, ultraviolet and infrared photography, DNA smear are used to compile the evidence of bite marks. ${ }^{22,31-34}$ The DNA technique is employed in cases particularly when the human bite marks are distorted. Manoeuvres involving DNA in forensic dentistry provide a new ray of hope when the regular methods fail due to the intensity of heat and shock. ${ }^{35}$ To standardize the analysis of bite marks, the ABFO (American Board of Forensic Odontostomatology) established guidelines in 1986. ${ }^{36}$ Human bite mark analysis includes clear images, gentle scrubbing of the affected site, followed by recording of alleged individual's tooth. ${ }^{20}$ The suspected dentition is recorded by making impression and examining it for precise tooth indentations with the obtained cast. Bite mark analysis if performed with the above protocols, can be worth it to vindicate before the law, even if the documentation of the anonymous person is found to be irrelevant. Despite the ABFO guidelines, discrepancies do exist in the obtained results, which have further given pavement for the digital technology. Web based survey dictates that, most of the odontologist's prefer digital method to detect, collect and examine bite marks. ${ }^{37}$ The Dorion method is preferred by few forensic dentists which demands the removal of crushed tissue for microscopic analysis.

New approaches like scanning electron microscopy, computer-enhanced digitization, dental print software, and xeroradiology are mutually adopted by other forensic dentists. ${ }^{38}$ SCIP (Shape Comparison Interactive Program) recommended as a simple, accurate and objective means of comparing bite marks in suitable forensic cases. It is advised as a routine means of eliminating suspects in bite mark cases. ${ }^{39,40}$ Honestly, the evidence produced before the law, demands precise information of bite marks, so as to account the suspect for the committed crime. 2D (2 Dimensional) methods satisfy the former statement in revealing accurate data of the bite marks. The two dimensional overlay techniques with the aid of Adobe Photoshop (Mountain View, CA, USA) are used universally to examine the bite marks. ${ }^{41}$ On the contrary; these concepts were overcome by the new 3D methods due to the improved resolution in images. 3D substantiation is based on 3D/CAD (Computer aided design) supported photogrammetry (FPHG) and the application of a 3D surface scanner. ${ }^{33}$ Minor photographic distortion of bite marks are totally eradicated with the later technique. Few forensic investigations demand an adequate probing of the photograph because of the poor dimensions of bite mark. $3 D$ assures in deriving a firm answer by its exclusive analysis of the bite mark photograph. Moreover the analysis of soft tissue, bones and skin bruises can be interpreted with the involved instruments. ${ }^{42}$ Forensic examination of bite marks is considered to be trouble shooting, when a $3 D$ object is registered into a $2 D$ aperture. 3-D cone beam computed tomography (CBCT) has better features to uncover ostensible persons when compared with the raditional method. ${ }^{43}$ Biggest tasks in forensic dentistry are matching the marks traced in human skin, owing to the presence of distortion and the time delayed between the onset and examination. ${ }^{34}$ Proof recovered from the crime scene, especially of bite marks traced in skin can be a turning point to the forensic cases.

\section{Dental identification in mass disasters}

Dental identifications have played a crucial role in disaster situations. Dental description involves the routine procedure, as performed during a case work of a dead person, but the conditions under which the 
whole procedure performed is complex because of the emotional environment in a disaster. ${ }^{44}$ The first report of dental recognition in mass disaster was written by Dr Ascor Amoedo and popularly known as the father of forensic odontology for his extensive contribution in forensics. ${ }^{45}$ Description of dead person's is a challenging duty, particularly during disasters. Since ages, it's being contemplated that dental identification is the reliable method in identifying victims in mass disasters. ${ }^{46-48}$

The attack of World trade centre on 9/11, 2001 claimed 2,752 lives and the recovered bodies were severely fragmented owing to the collapse of the twin towers. 21,812 pieces of human remains have been obtained from the tragic incident. ${ }^{49}$ Clinical investigation of the fragments and $X$ - rays were carried out by the forensic dentists. On relating the retrieved data with the present dental records and $X$ rays, approximately $80 \%$ of the victims were positively identified, who lost their lives at the World Trade Center. ${ }^{50}$ An example of intensive, almost inhuman forensic identification work, was seen after the tsunami disaster on the 26th of December 2004 in Southeast $\mathrm{Asia}^{32}$ during the bombings in London on the 7th of July 2005, and after the landfall of hurricane Katrina in and around Louisiana on the 29th of August 2005. ${ }^{51}$ Similarly, dental comparisons proved to be one of the prime source in identifying $79 \%$ of the South East Asia tsunami victims ${ }^{52}$ and $46.2 \%$ of those identified in the Indian Ocean tsunami disaster. ${ }^{53}$ Methods of operation exercised during disaster victim identification (DVI), consist of forensic dentistry, forensic pathology, fingerprints and DNA profiling. The latter type has created a major impact in the forensic discipline and it's been successfully used in portraying the victim's aftermath mass casualties and tragic accidents. ${ }^{54-57}$ Over the past decade, traditional approaches are employed for disaster victim identification in greater number of cases; meanwhile DNA-typing proved to be superior when the remaining techniques failed. Judicial proceedings strongly agree the results of DNA profiling in human identification, considering its accuracy in retrieved data. Molecular process is considered to be the effective technique in disaster victim identification. ${ }^{35}$ Even small portions of biological remnants serve to be a good sample for the genetic methodologies, which further adds to the success of molecular biology in DVI. ${ }^{58}$ Saliva is recognized as good source of DNA, because of its retrieval by non-intrusive methods and it is favourable even when conserved under diversified circumstances. ${ }^{59}$ When the adequate amount of sample is not available to derive a conclusion on the forensic case, thereupon analysis of mitochondrial DNA profiling yields concrete results. Mitochondrial DNA is known to be a robust procedure during forensic case works, and can aid in revealing the identity of the deceased, despite the absence of ante mortem details. ${ }^{60-62}$

The well known phenomenon after the occurrence of mass calamities, involve compilation of huge dental records and specimens in the process of identifying the unnamed individuals. Collaterally, organized and meticulous protocols must be adhered while categorizing the obtained samples. To maintain the standards in the practical manoeuvres, International Society for Forensic Genetics, tabulated the guidelines to marshal the forensic dentists during accumulation of specimens. The devised guidelines have been put forth based on the knowledge acquired from recent disasters, violent assaults and mass casualties. ${ }^{63}$ Irrespective of the extreme conditions after the natural / man- made disasters, teeth withstand the calamities and thereby serve as leading-edge in DVI. The former statement can be taken into account and ascertained that these organic substances help the forensic team at crucial situations, when the traditional approaches have failed. A fundamental rule required for the forensic dentists involved in compiling data during natural / manmade disasters is disaster alertness. ${ }^{64}$ Apart from the honest efforts rendered by the forensic team, the DVI undoubtedly requires the service of pioneered people to arrive at definitive conclusions. ${ }^{9}$ On the grounds of humanity, the dedicated service and commitment of forensic team support the families in healing their mental agony of missing a loved one.

\section{ANTHROPOLOGIC EXAMINATION}

Majority of the osteologic information is collected from anthropologic investigation. Forensic dentist can be of assistance to forensic anthropologists during the process of identifying deceased persons. The structure of skull, provides enormous information pertaining to age, gender and ancestory. Forensic dentists can anticipate the human race from the three prime groups: Caucasoid, Mongoloid and Negroid. Auxiliary information can be obtained with the presence of shovel shaped incisors, cusp of Carabelli, which further facilitate in estimation of the ancestry. ${ }^{65}$ The dental anatomy reveal positive facts to the forensic dentists in predicting individual's chronological age. ${ }^{66}$ Children's age can be conceived by interpreting tooth development and proportionate comparison to development charts, probably to an accuracy of 1.6 years $^{67}$ Disastrous episodes, where soft tissues are deprived, particularly in infants the existence of neonatal line in enamel guides during forensic operations. Essential data could be gained from the enamel structures and neonatal line, when examined through scanning electron microscope. ${ }^{68}$ Measuring the postnatal hard tissue development in the infant reveals the exact period of their survival in days. ${ }^{69}$ In some unforeseen situations, soft tissues are 
badly decomposed and the determination of persons individuality relies on remains of skeleton structures. During such critical situations, the presence of an anomaly in the corpse proves to be a positive sign in distinguishing the deceased. The obtained valuable information from the anomalies can aid the legal investigation. ${ }^{70}$ The performed dental procedures and morphological variations of the tooth serve as important aspect behind the description of suspect's/ victim's oral structures. Amalgam restorations, despite being outdated are still considered to yield positive information in forensic investigations. Brand names of the restorative resins do impart pertinent facts, in cases where the dental status cannot be gauged owing to the disrupted dentition. ${ }^{71}$ Forensic dentists can define their search with the presence of unique restorative materials, orthodontic, removable appliances and labelled dentures. ${ }^{72-75}$ Unusual wear patterns noticed in the teeth indicate the previous orthodontic treatment. ${ }^{76}$ Still, individualized information regarding personal habits, behaviours, socio-economic status can be updated from postmortem dental profiling. Canine teeth retain more importance in forensic studies, by virtue of its anatomical position and stability in the oral cavity. The canine teeth apparently are claimed to be invulnerable as they survive even in utmost calamities like storms and plane accidents. ${ }^{77}$ Mandibular canine indexes helps to distinguish the gender and in calculating the age of dead persons. ${ }^{77}$

Peculiar characteristics of the dentition scale down the investigation process in most of the legal cases. Equivalently, the lip and palatal rugae are authenticated to be special features, which aid in procuring definite conclusions in the corpse. Lip patterns being invariable and enduring all along the human life, ascertains that these patterns can infer redundant facts respective to the speculate. ${ }^{78}$ Palatal rugae patterns are utilized in forensic investigations as they remain stable during the whole spell of the human. ${ }^{79,80}$ Rugae are safeguarded from the extreme temperatures and catastrophe, by virtue of their favourable anatomical location in the oral cavity. This gives the privilege for rugae patterns to be applied in forensic inquisitions. ${ }^{81}$ Medico legal affairs consider rugoscopy to be one among the uncommon maneuvers because of its inaccuracy. Meanwhile, the technique is considered to be an interim approach of examining bodies $^{82}$ notably in burned cases. $^{78}$ Palatal mucosa studies affirm the rugae pattern as a trustworthy description, because of its invariable growth despite the application of palatal expanders. ${ }^{83}$ Durability, consistence and stability of the rugae admit it to be as an appropriate means in describing human identity. ${ }^{84-86}$

New laboratorial techniques like aspartic acid racemisation help the forensic dentists in age determination. ${ }^{87}$ Racemisation yields information, pertaining to the human dentin. Aspatic acid shows optical phantasm in dextro (D) or laevo (L) forms. The calculations of the $D / L$ values provide the accurate age of the suspect. ${ }^{88}$ Approaches in anthropologic investigations have achieved better results with the aid of computers. Computer is a valuable tool for the techniques involving facial superimposition. The underlying skeletal structures and tissues can be inspected and thus recontouring of the soft tissues can be accomplished with accuracy ${ }^{89}$ Three dimensional image registration is employed as a robust tool for human identification, which ensures that accurate data can be recorded from the dentition. ${ }^{90}$ Recent research suggest the application of an RFId ( Radio frequency identification ) for body labelling that was implemented in tsunami disaster in 2004. ${ }^{91}$ The novel technology works on a simple principle wherein a miniature transponder is embedded in the teeth, dental prosthesis ${ }^{92}$ which serves as a tool for forensic dental recognition. ${ }^{93,94}$ The mangled corpse could be described with the stored information ( patient's personal details) in a small transponder and obtained data can be communicated via radio to a reader linked to computer ${ }^{95}$ Cited tag is cost- effective, besides the integrated microchip favors general dentists, who can perform the recognition of corpse with ease. Chiefly, general dentists can execute the identification, without any exclusive coaching. Computer associated crystalline assessment afford valid facts related to age evaluation. Digital procedures have achieved good response in legal jurisdictions because of its high accuracy in portraying the fine structures of teeth. ${ }^{96}$ Human identification from dental structures is contemplated as the peerless tool for post-mortem biometric identification as they undergo most post-mortem procedures which destroy the body tissues.

\section{WAY FORWARD}

Forensic identifications, by their nature, are multidisciplinary team efforts that usually involve the coordination and cooperation of law enforcement officials, forensic pathologists, forensic odontologists, forensic anthropologists, serologists, criminalists and other specialists as deemed necessary. ${ }^{97}$ Dental discipline affords credible information pertaining to the recognition of human remains following offense / disasters. Regardless of the crucial circumstances, where in the bodies are far away from naked explanation, dental records do guide in obtaining data from the unidentified individuals. Forensic dentistry is the distinctive and cardinal method of human recognition and the preservation of dental records by the dentist $s$ could be of assistance during forensic maneuvers. ${ }^{98}$ One 
must not deny that it is the foremost responsibility of a dentist to aggregate the dental data and conserve the particulars in their routine dental practice, which would positively guide the legal authorities in recognition of the unnamed individuals. ${ }^{99}$ Methodical aggregation of the dental records is essential so as to enhance the human description ensuing disasters and violent attacks. Tooth is hard and tenacious which symbolizes it to be employed during medico-legal issues. Awareness of the significance's in forensic dentistry will aid medicaldental clinicians to preserve the evidence and benefact the legal sovereignty.

\section{REFERENCES}

1. Sansare K. Forensic odontology. Historical restorations to changes brought about by environmental perspective. Indian J Dent Res. 1995;6:55-7.

2. Shamim T. Forensic odontology. J Coll Physicians Surg. 2010;20:1-2.

3. Verma AK, Kumar S, Rathore S, Pandey A. Role of dental expert in forensic odontology. Natl J Maxillofac Surg. 2014;5:2-5

4. Prabhu SR, Daftary DF, Wilson DK, Johnson NW. In: Oral diseases in the tropics. 2nd ed. United States of America (USA): Oxford University Press; 1992. p. 752-64.

5. Neville B, Douglas D, Allen CM, Bouquot J. In: Oral \& maxillofacial pathology. Philadelphia: WB Saudenrs Co; 2002. p. $763-83$.

6. Jones DG. Odontology is final piece to grimm puzzle. J Calif Dent Assoc. 1998; 26:650- 1.

7. Shyamal bar, Surajit Bose. Forensic odontology: The new aspects of forensic science and important role of dentistry. Sci and Cult. 2010;76:135-7.

8. Masthan KMK. Age and sex. In: Textbook of forensic odontology. 2nd ed. New Delhi. Jaypee Brothers Medical Publishers; 2009. p. 92-5.

9. Pretty IA, Sweet D. A look at forensic dentistry--Part 1: the role of teeth in the determination of human identity. Br Dent J. 2001;190:359-66.

10. Introna $\mathrm{F}$, Santoro $\mathrm{V}$, De Donno $\mathrm{A}$, Belviso $\mathrm{M}$. Morphologic analysis of third molar maturity by digital orthopantomograohic assessment. Am J Forensic Med Pathol. 2008;29:55-61.

11. Borrman H, Grondahl HG. Accuracy in establishing identity in edentulous individuals by means of intraoral radiographs. J Forensic Odontostomatol. 1992;10:1-6.

12. Whittaker DK. An introduction to forensic dentistry. Quintessence Int. 1994;25:723-30.

13. Liversidge HM, Lyons F, Hector MP. The accuracy of three methods of age estimation using radiographic measurements of developing teeth. Forensic Sci Int. 2003;131:22-9.

14. Ramasamy C. Dentistry's cardinal role in forensic odontology. Iranian J Publ Health. 2014;43:1152-3.

15. Shah Samir. Abaza Ayman, Ross Arun, Ammar Hany. Automatic tooth segmentation using active contour without edges. The Biometric Conference; 2006 Sep 19-21; Baltimore. Available from:URL: csee.wvu.edu/ ross/pubs/Shah Tooth Segmen.
16. Yang F, Jacobs R, Wilhems G. Dental estimation through volume matching of teeth imaged by cone-beam $\mathrm{CT}$. Forensic Sci Int. 2006;159:78-83.

17. Babar MG, Iqbal S, Jan A. Essential guidelines for forensic dentistry. Pakistan Oral Dent J. 2008;27:79-84.

18. Aksu MN, Gobetti JP. Am J Forensic Med Pathol. 1996;17:136-40

19. Furness J. A general review of bite-mark evidence. Am J Forensic Med Pathol. 1981; 2:49-52.

20. Lessig R, Wenzel V, Weber M. Excli Journal. 2006;5:93-102.

21. Sweet D, Pretty IA. A look at forensic dentistry--Part 2: teeth as weapons of violence--identification of bitemark perpetrators. Br Dent J. 2001; 190(8):415-8.

22. Pretty IA, Sweet D. Digital bite marks overlays-an analysis of effectiveness. J Forensic Sci. 2001;46:1385-91.

23. Utsuno H, Kanoh T, Tadokoro O, Inoue K. Preliminary study of post mortem identification using lip prints. Forensic Sci Int. 2005;149:129-32.

24. Dorion RBJ. Patterns, lesions and trauma mimicking bitemarks. In: Dorion RBJ, editor. Bitemark Evidence. New York (NY): Marcel Dekker; 2005. p. 389-413.

25. Chris Greenwood. Body of schoolgirl Tia Sharp was identified by dental records because of decomposition. [Online]. 2012 Aug 16. Available from:URL:http://www. dailymail.co.uk/news/article-2189195/Tia-Sharp-latestBody-identified-dental-records-decomposition.html

26. Albert Fish, serial killer and cannibal: inside the grisly 1928 murder of Grace Budd. [Online]. 2013 Apr 3. Available from:URL:http://www.nydailynews.com/new-york/1928murder-grace-budd-albert-fish-gallery-1.1277430

27. Basavaraj F Kattimani. Nirbhaya case: Dharwad college helped with forensic analysis. [Online]. 2013 Sep 13. Available from:URL: http://timesofindia.indiatimes. com/city/hubli/Nirbhaya-case-Dharwad-college helpedwith-forensic-analysis/articleshow/22528229.cms

28. Adobe photoshop.Connecticut police department. Forensic science lab. [Online]. Available from:URL:http:// partners.adobe.com/public/asn/en/partnerfinder/ ConnecticutPoliceCS_Fnl1

29. Brown KA. The identification of Linda Agostini. The significance of dental evidence in the Albury 'Pyjama Girl' case. A case report. Forensic Sci Int. 1982;20:81-6.

30. Kavitha R. Molecular techniques in forensic dentistry. J Forensic Odontol.2008;1:13-7. 
31. Bowers CM, Johansen RJ. Photographic evidence protocol: the use of digital imaging methods to rectify angular distortion and create life size reproductions of bite mark evidence. J Forensic Sci. 2002;47:178-85.

32. Fixott, Richard H. Forensic odontology. In: Richard H, editor. Dental Clinic of North America, Philadelphia: WB Saunders; 2001; p. 420.

33. Johansen RJ, Bowers CM. Forensic science communications. [Online]. 2001 Jul. Available from:URL:http://www.fbi. gov/about-us/lab/forensic-science-communications/fsc/ july2001/bowers.htm

34. Sheasby DR, MacDonald DG. A forensic classification of distortion in human bite marks. Forensic Sci Int. 2001;122:75-8.

35. Potsch L, Meyer U, Rothschild S, Schneider PM, Rittner C. Application of DNA techniques for identification using human dental pulp as a source of DNA. Int J Leg Med. 1992;105:139-43.

36. American board of forensic odontology. Inc: Guidelines for bite mark analysis. JADA. 1986;112:383-6.

37. Pretty IA. A web-based survey of odontologist's opinions concerning bitemark analysis. J Forensic Sci. 2003;48:1117-20.

38. Martin-de las Heras S, Valenzuela A, Javier Valverde A, Torres JC, Luna-del-Castillo JD. Effectiveness of comparison overlays generated with dental print software in bite mark analysis. J Forensic Sci. 2007;52:151-6.

39. Nambiar P, Bridges TE, Brown KA. Quantitative forensic evaluation of bite marks with the aid of a shape analysis computer program: Part 1: the development of "SCIP" and the similarity index. J Forensic Odontostomatol. 1995;13:18-25.

40. Nambiar P, Bridges TE, Brown KA. Quantitative forensic evaluation of bite marks with the aid of a shape analysis computer program: Part 2: "SCIP" and bite marks in skin and foodstuffs. J Forensic Odontostomatol. 1995;13:26-32.

41. Thali MJ, Braun M, Markwalder TH, Brueschweiler W, Zollinger, Naseem U Malik J, Yen K, Dirnhofer. Forensic Sci Int. 2003;135:115-21.

42. Brueschweiler W, Braun R, Dirnhofer, Thali MJ. Analysis of patterned injuries and injury-causing instruments with forensic 3D/CAD supported photogrammetry (FPHG): an instruction manual for the documentation process, Forensic Sci Int. 2003; 132:130-8.

43. Wu Y, Chen X, Shen Y, Yu J, TangY, Zhang Y, Zhu L et al. Effectiveness assessment of 3-D cone beam CT used in human bite marks identification. Journal of Biomedical Engineering. 2013;30:157-61.

44. Morlang WM. Dentistry's vital role in disaster preparedness. J Calif Dent Assoc. 1996; 24:63-6.

45. Barsley RE. Forensic and legal issues in oral diagnosis. Dent Clin North Am. 1993; 37:133-56.

46. Cairns FY, Herdson PB, Hitchcock GC, Koelmeyer TD, Smeeton WMI, Syneck BYL. Aircrash on Mount Erebus. Med Sci Law. 1981;21:184-8.
47. Clark DH. Postmortem dental identification in mass disaster. PhD dissertation, University of London; 1989.

48. Hutt JM, Ludes B, Kaess B, Tracqui A, Mangin P. Odontological identification of the victims of flight AI.IT 5148 air disaster Lyon-Strasbourg 20.01.1992. Int J Legal Med. 1995;107:275-9.

49. Mark Desire. Handling Mass Fatalities: advancements since $9 / 11$ by the office of the chief medical examiner's world trade center identification unit. The Police Chief. 2011;78:26-28.

50. NC dentists help identify bodies in New York. Triangle Business Journal. [Online]. 2011 Oct 11. Available from:URL:http:/ / www.bizjournals.com/triangle/ stories $/ 2001 / 10 / 08 /$ daily31.html?page=all

51. Brannon RB, Morlang WM. The USS Iowa disaster: success of the forensic dental team. J Forensic. Sci. 2004;49:1067-8.

52. James. Thai tsunami victim identification overview to date. J Forensic Odontostomol. 2005;23:1-18.

53. M. Petjua, Suteerayongprasertb A, Thongpudc R, Hassirid $\mathrm{K}$. Importance of dental records for victim identification following the Indian ocean tsunami disaster in Thailand. Public Health. 2007;121:251-7.

54. Morgan OW, Sribanditmongkol P, Perera C, Sulasmi Y, Van Alphen D, Sondorp E. Mass fatality management following the South Asian Tsunami Disaster: case studies in Thailand, Indonesia, and Sri Lanka. PLoS Med. 2006;3:809-15.

55. Ed Pilkington, Mark Tran. Tooth solves Hatshepsut mummy mystery. [Online]. 2007 June 27. Available from:URL:http:/ / www.theguardian.com/world/2007/jun/27/egypt.science

56. Mike Eckel. DNA tests may confirm IDs of Russian Tsar's children. [Online]. 2008 April 30. Available from: http:// news.nationalgeographic.com/news/2008/04/080430-APczar.html.

57. Attorneys say a Gacy victim was misidentified. USA today. [Online]. 2012 Oct 26. Available from:URL: http:// www.usatoday.com/story/news/nation/2012/10/26/ attorneys-gacy-victim-dna/1659741/.

58. Mandrekar PV, Flanagan L, Tereba A. Forensic extraction and isolation of DNA from hair, tissue and bone. Profiles DNA. 2002;5:11-13.

59. Koh D, Ng DP, Choo SG, Ng V, Fu Q. Effect of storage conditions on the extraction of PCR quality genomic DNA from saliva. Clin Chim Acta. 2004;343:191-4.

60. Brittania J, Bintz MS, Groves B, Dixon MS, Mark R Wilson. Simultaneous detection of human mitochondrial DNA and nuclear-inserted mitochondrial-origin Sequences (NumtS) using forensic mtDNA Amplification strategies and pyrosequencing technology. J Forensic Sci. 2014;59:1064-73.

61. Forensic DNA: mitochondrial DNA. [Online]. 2012 Oct 11. Available from:URL: http://nij.gov/topics/forensics/ evidence/dna/research/pages/mitochondrial.aspx

62. Kolude B, Adeyemi BF, Taiwo JO, Siqbeku OF, Eze UO. The role of forensic dentist following mass disaster. Ann Ib Postgrad Med. 2010;8:111-7. 
63. Prinz M, Carracedo A, Mayr WR, Morling N, Parsons TJ, Sajantila et al. International Society for Forensic Genetics .DNA Commission of the International Society for Forensic Genetics (ISFG): recommendations regarding the role of forensic genetics for disaster victim identification (DVI). Forensic Sci Int Genet. 2007;1:3-12.

64. Pretty IA, Webb DA, Sweet D. The design and assessment of mock mass disasters for dental personnel. J Forensic Sci. 2001;46:74-9.

65. Whittaker DK, Rawle LW. The effect of conditions of putrefaction on species determination in human and animal teeth. Forensic Sci Int. 1987;35:209-12.

66. Acharya AB. Forensic dental age estimation by measuring root dentin translucency area using a new digital technique. J Forensic Sci. 2014;59:763-8.

67. Soomer, Helena Ranta, Michael J Lincoln, Antti Penttilä, Edvitar Leibur. Reliability and validity of eight dental age estimation methods for adults. J Forensic Sci. 2003; 48:149-52.

68. Mahija Janardhanan, Umadethan B, KR Biniraj, RB Vinod Kumar RB, Rakesh S. J Forensic Dent Sci. 2011;3:8-13.

69. Jayaraman J, King NM, Roberts GJ, Wong HM. Dental age assessment: are demirjian's standards appropriate for southern Chinese children? J Forensic Odontostomatol. 2011;29:22-8.

70. Auslebrook WA, Iscan MY, Slabbert JH, Becker P. Superimposition and reconstruction in forensic identification: a survey. Forensic Sci Int. 1995;75:101-20.

71. Bush MA, Miller RG, Norrlander AL, Bush PJ. Analytical survey of restorative resins by SEM/EDS and XRF: Databases for Forensic Purposes. J Forensic Sci. 2008;53:419-25.

72. Andrea Sayuri Silveira Dias Terada, Laís Gomes de Araujo, Luiz Renato Paranhos, Teresa Cristina, Pantozzi Silveira, Marco Aurélio Guimarães. Orthodontic use of documentation in identification of a skeletonized body in legal dental practice. Int. J. Odontostomat. 2014;8:41-46.

73. Shreya S Covenkar, Sujatha Gopal. Micro secure digital card: a novel method for denture identification. J Forensic Dent Sci. 2014;6:183-86.

74. Murugesh M, Selva Ganesh. Denture labelling in forensic dentistry. J Forensic Dent Sci. 2014;6:67-9.

75. Silva RF, Chaves P, Paranhos LR, Lenza MA, Daruge Junior E. Use of orthodontic records in human identification. Dental Press J Orthod. 2011;16:52-7.

76. Gupta BN. Occupational diseases of teeth. J Soc Occup Med. 1990;40:149-52.

77. Boaz K, Gupta C. Dimorphism in human maxillary and mandibular canines in establishment of gender. J Forensic Odontol. 2009;1:42-4.

78. Caldas IM, Magalhães T, Afonso A. Establishing identity using cheiloscopy and palatoscopy. Forensic Sci Int 2007:165:1-9.
79. Subashini Jakfar. Role of palatal rugae patterns (rugoscopy) in forensic field. Dental Journal. 2011;16:194-6.

80. Li Bing, Xiu Ping Wu, Yin Feng, Yu Jin Wang, Hong Chen Liu. Palatal rugae for the construction of forensic identification. Int J Morphol. 2014;32:546-50.

81. Kallianpur S, Desai A, Kasetty S, Sudheendra U, Joshi P. An anthropometric analysis of facial height, arch length, and palatal rugae in the Indian and Nepalese population. J Forensic Dent Sci. 2011;3:33-7.

82. Patil MS, Patil SB, Acharya AB. Palatine rugae and their significance in clinical dentistry: review of the literature. JADA. 2008;139:1471-8.

83. Ana A Barbieri, Raque A, Scoralick, Suely CM, Naressi, Mari EL et al. The evidence of the rugoscopy effectiveness as a human identification method in patients submitted to rapid palatal expansion. J of Forensic Sci. 2013;58:235-38.

84. Briñón E. Palatograma Legal Programado. Rev del Circ. Argentino Odontol. 2011; 68:11-15.

85. Pereira $\mathrm{CP}$, Mendonca $\mathrm{MCN}$, Vieira, Duarte NP. Medicina Dentária Forense. primeira. Lisboa-Porto: Lidel. 2012;103:71-9.

86. Mutalik VS, Menon A, Jayalakshmi N, Kamath A, Raghu AR Utility of cheiloscopy, rugoscopy and dactyloscopy for human identification in a defined cohort. J Forensic Dent Sci. 2013;5:2-6.

87. Ritz-Timme, Cattaneo C, Collins MJ, Waite ER, Schütz HW, Kaatsch HJ, Borrman HI. Age estimation: the state of the art in relation to the specific demands of forensic practise. Int J Legal Med. 2000;113:129-36.

88. Ranganathan K, Rooban T, Lakshminarayanan V. Forenesic odontology: a review. J Forensic Odontol. 2008;1:4-12.

89. Wood RE, Clark B, Brooks SE, Blenkinsop B. Combined physical and computer-aided facial reconstruction in human skeletal remains. Can Soc Forensic Sci J. 1996;29:195-203.

90. Abduo J, Bennamoun M. Three-dimensional image registration as a tool for forensic odontology: a preliminary investigation. Am J Forensic Med Pathol. 2013;34:260-6.

91. Meyer HJ, Chansue N, Monticelli F. Implantation of radiofrequency identification device (RFID) microchip in disaster victim identification (DVI). Forensic Sci Int. 2006;157:168-71.

92. Millet $\mathrm{C}$, Jeannin C. Incorporation of microchips to facilitate denture identification by radio frequency tagging. J Prosthet Dent. 2004;92:588-90.

93. Thevissen PW, Poelman G, De Cooman M, Puers R, Willems G. Implantation of an RFID-tag into human molars to reduce hard forensic identification labor. Part 1: working principle. Forensic Sci Int. 2006;159:33-9.

94. Thevissen PW, Poelman G, De Cooman M, Puers R, Willems G. Implantation of an RFID-tag into human molars to reduce hard forensic identification labor. Part 2: physical properties. Forensic Sci Int. 2006;159:40-6. 
95. Nuzzolese1 E, Marcario V, Di Vella G. Incorporation of radio frequency tag in dentures to facilitate recognition and forensic human identification. The Open Dentistry Journal. 2010;4:33-36.

96. Acharya AB. A new digital approach for measuring dentin translucency in forensic age estimation. Am J forensic Med Pathol. 2010;31:133-7.

97. Fixot RH, Arendt D, Chrz B, Filippi J, Mcgivney J, Warnick A. Role of dental teams in mass fatality incidents. Dent Clin North Am. 2001;45:271-92.
98. Soomer H, Lincoln MJ, Ranta H, Penttila A, Leibur E. Dentists' qualifications affect the accuracy of radiographic identification. J Forensic Sci. 2003;48:1121-26.

99. Ramasamy C. A select list of international cases involving forensic odontology, 49-2013 AD. [Online]. 2014 Oct 17. Available from: http://www.historyofdentistry.co.uk/ magazine.htm. 